\title{
Is Our Land Being Abused?
}

\author{
By Stephanie Stewart, Moose Jaw
}

It is surprising how one thing leads to another, and a line of thought may take one into unexpected places. Dr. Ledingham's talk on "The Grasslands Tour" at the Moose Jaw Natural History Society meeting on January 8 was a straightforward illustrated talk on the tour of Western Canadian grasslands conducted in connection with the International Bcitanical Congress last summer. It was given by a professional botanist for a group of people avowedly interested in natural history and the outdoors, but for one listener it raised a number of questions.

To whom do the grasslands belong? Is there any planned range management in Western Canada in order to control grassland use? How does management of the grasslands compare with the control of other natural resources in Canada? What are "natural resources" afiter all?

isurely one of these so-called "natural resources," and only one, is basic-the land, for all cthers derive from it . . minerals beneath the land; waters flowing from the land; fish living in the water; plants growing on the land; birds and animals living among and on what grows there.

There is legislation controlling the use of our forests. There are laws limiting the hunting of wild game, and the taking of fish, laws pertaining to mining-all designed to conserve these resources so that they may noit be depleted but perpetuated.

But what of the land itself? Of what avail bag limits and hunting seasons on duck and deer, if the habitat of the duck and deer are to vanish. To what purpose do the federal and provincial governments spend hundreds of thousands of dollars yearly to study and develop new and better farming practices if it is left to the conscience of the individual to protect and preserve the land. Anyone may buy a car, but society has placed definite limits on the manner in which it may be operaited - where, how and by whom. Have similar restrictions been placed on those who own the land?

Farming is a business-and a risky and uncertain one. Farmers, like business men in other fields, need to make a profit in order to stay in business; good farmers, like good business men in other fields, study constantly to improve their methods, to make the best use of their "plant." Sometimes the business man finds that his plant is not adequate to do the job desired of it and without remodelling or expansion, or a realigning of system, it cannot be operated profitably. Sometimes the land simply is not fit to produce the crop - grain, grass or animal-demanded. But who decides? Must the land be impoverished, worn ouit, leached and drifting before it is admitted that it is being abused? No one wishes to raise the grim spectre of the "thirties" but can that ghost ever be laid while sub-marginal land is put to the plough and natural grassland persistently over-grazed in order to operate at a profit however small, and while programmes of replenishment and reclamation that could be implemented are ignored for lack of money, failure to recognize their importance, or sheer indifference.

Yet the results are clear enough. The far-seeing, thinking farmer does make a profit, does enjoy a good living and often inherits a farmstead that is the showplace of his district. But here, as in so many matters, the far-sighted, far-thinking are few: the complacent and indifferent are many. Are the few enough to leaven the dough?

Egypt and North Africa were the granaries of the Greek and Roman worlds-what do they produce today? Palestine wras once a "land flowing with milk and honey," yet today a large part of the endeavour of the Republic of Israel is bent toward reclaiming a desert. Twin rivers watered a land that made the name of Babylon synonymous with plenty -as long as the soil endured. But the soil did not endure-and neither did the civilization it nuntured. Will this happen here? 


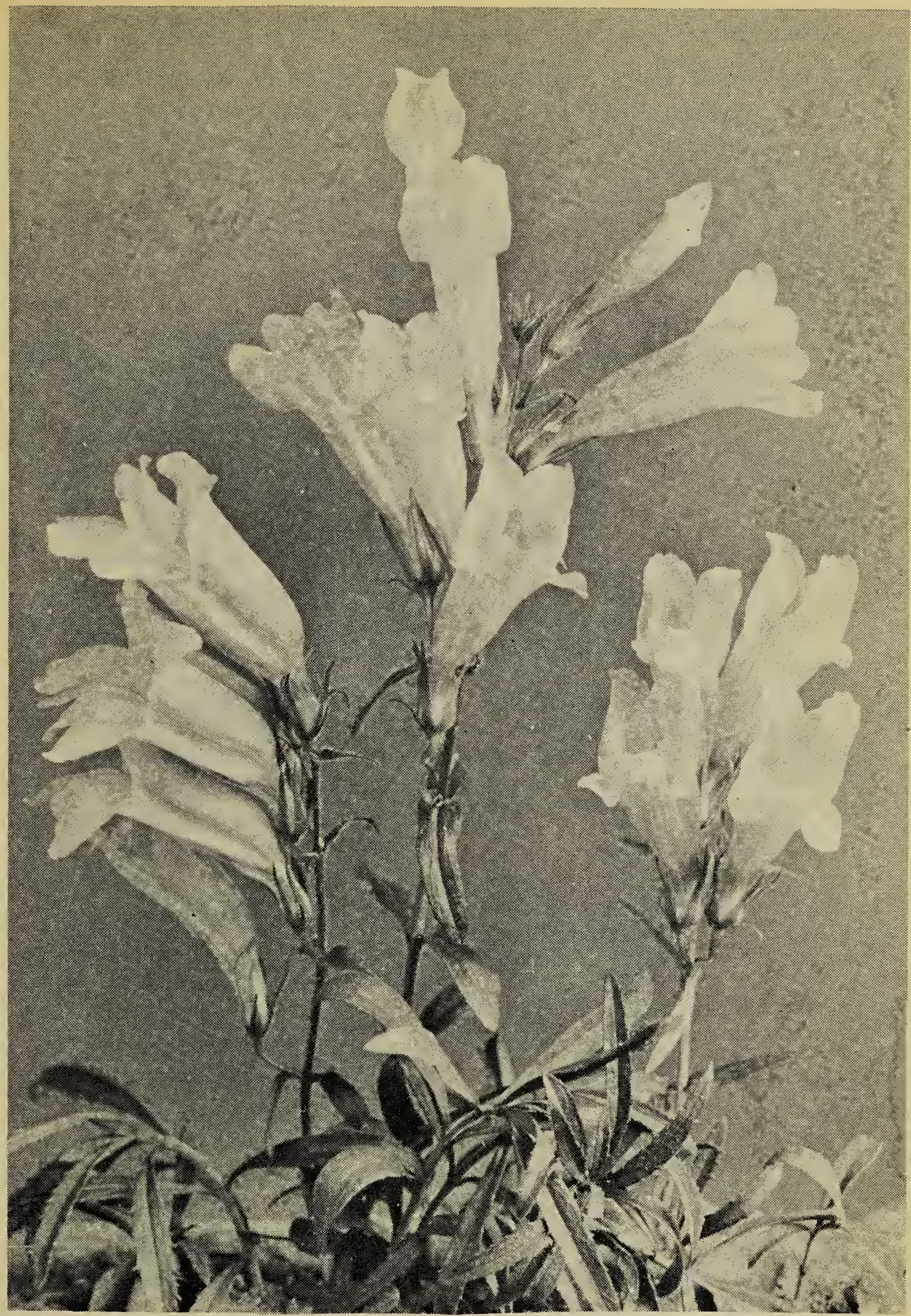

Photo by W. C. McCalla.

Penstemon fruticosa (Pursh) Greene subspecies scouleri (Lindl.) Penn. \& Keck.

The last issue of the Blue Jay showed Dr. McCalla's picture of Penstemon nitidus Dougl. which is common on dry banks in southern Saskatchewan. The Shrubby Penstemon shown above does nct occur on the prairies but it is present, though rather rare, in southwestern Alberta (E. H. Moss, Flora of Alberta, 1959).

The Shrubby Penstemon has stems 8 to 15 inches high. It is somewhat woody at the base. The flowers are a beautiful lilac-purple colour. Dr. McCalla says that, like Penstemon nitidus, plants moved to his Calgary garden have done very well in full sunshine. 